\title{
Verdade-acontecimento e alteração no pensamento de Michel Foucault
}

\section{Truth-event and alteration in the thought of Michel Foucault}

\section{Daniel Verginelli Galantin*}

Pontifícia Universidade Católica do Paraná, Curitiba, PR, Brasil

\section{Resumo}

Neste artigo examinamos uma possível repercussão da separação entre uma verdade-demonstração e uma verdade acontecimento, em distintos momentos do pensamento de Foucault. Se Foucault descreve seu pensamento sob a série da verdade-acontecimento, sugerimos que essa série ainda pode ser estendida para a definição de seus livros enquanto livros-experiência. Neste caso, também a relação entre experiência e ficção, no sentido da produção de algo que não existe ainda, vincula seu pensamento à verdade-acontecimento. Tentamos descrever o sentido dessa produção nos termos de uma alteração, irredutível a uma alteridade definida por uma filosofia primeira. Finalmente, defendemos que também a forma com que a parresía é trabalhada em seu último curso segue o mesmo eixo da verdade-acontecimento. Todos esses elementos fornecem bases para que pensemos o estatuto da verdade do pensamento de Foucault, assim como ajudam a explicar como ele não pode remeter a qualquer normatividade.

Palavras-chave: Foucault. Parresía. Verdade. Alteração.

*DVG: Doutor em Filosofia, e-mail: d.galantin@gmail.com 


\section{Abstract}

In this article, we examine a possible repercussion of the separation between a truth-demonstration and a truth-event in different moments of Foucauldian thought. If Foucault describes his own thought by the series of truth-event, we suggest that this series may be extended to his description of his own books as books-experience. In this case, the relation between experience and fiction, in the sense of the production of something that doesn't yet exists, also links his thought to a truth-event. All these elements provide the basis which allows us to think the status of truth in Foucauldian thought, as well as help to explain the detachment from any normativity.

Keywords: Foucault. Parres. Truth. Alteration.

\section{Introdução}

Um dos principais objetivos das pesquisas que constituem o pensamento de Michel Foucault é elaborar uma história da verdade, retirando dela algumas consequências ético-políticas. $\mathrm{O}$ fato de fazer uma história da verdade significa que Foucault não visa as regras formais de todo e qualquer conhecimento verdadeiro, não importando a qual espaço ou tempo ele pertença. Quando, ainda na década de 1960, Foucault separa a noção de conhecimento evocada pela epistemologia, da noção de saber ${ }^{1}$ referida por sua arqueologia, ele está demarcando a diferença de seu estudo com relação à questão das regras formais e a-históricas estudadas pela epistemologia e pela lógica. Contudo, elaborar uma história da verdade também não significa fazer da história o palco em que a verdade se manifesta no tempo até ser finalmente revelada em sua totalidade por um progresso da razão, ou oculta por se distanciar de sua origem. Quando, na década de 1970, através de Nietzsche (e de parte dos historiadores da École des annales), Foucault

1 Em linhas gerais, ao invés de perguntar pela origem do conhecimento do lado das funções transcendentais do sujeito ou de suas capacidades empíricas, Foucault o considera enquanto um acontecimento histórico que obedece a determinadas regras variantes. Sobre isso, ver os livros de Candiotto (CANDIOTT0, 2010, p. 46-50), capítulo III e IV de Machado (MACHAD0, 2006), e o livro de Araújo (ARAÚJ0, 2008). 
formula uma noção genealógica de história, avessa à noção de origem utilizada pela fenomenologia, e avessa à história hegeliana da razão, ele está demarcando a diferença de sua genealogia com relação a essas outras formas de estudar a história da verdade.

Contudo, uma objeção reiterada ao pensamento foucaultiano é o fato dele furtar-se a responder justamente qual seria, então, o seu lugar, se ele pertence ou não à verdade, caindo, caso responda positivamente, numa contradição performática, e, em caso negativo, num relativismo ou irracionalismo ${ }^{2}$. É perfeitamente possível encontrarmos nos textos arqueológicos e genealógicos respostas a estas questões, assim como demarcar atribuições indevidas ao pensamento de Foucault. Com este artigo, procuramos entrar também neste debate ao levantarmos a questão de fundo sobre o estatuto da verdade no e do pensamento de Foucault. Começaremos então, levantando elementos textuais relativos a uma observação sobre a história da verdade feita por Foucault no curso O poder psiquiátrico, em 1974.

\section{Verdade-constatação e verdade acontecimento}

Na aula de 23 de janeiro de 1974, Foucault interrompe sua investigação sobre a forma com que o saber psiquiátrico foi investido aos poucos pelo poder disciplinar, para apresentar uma pequena história da verdade. Essa história serve de base para compreender tanto o método foucaultiano, quanto os processos pelos quais o saber psiquiátrico foi colonizado por uma tecnologia disciplinar de poder. Em nosso caso, vamos nos focar no primeiro ponto, a saber, como essa pequena história da verdade diz muito sobre a forma como o pensamento foucaultiano se constitui, e sobre como ele considera a sua própria verdade.

Foucault mostrará a existência, em linhas gerais, de duas grandes formas da verdade no ocidente, sendo que, historicamente, a modernidade seria marcada pelo prevalecimento de uma delas sobre a outra. Uma delas é aquela que Foucault denomina enquanto verdade-apofântica, ou verdade-demonstração, ou ainda, verdade-céu. Neste

2 Sobre isso ver os capítulos que Habermas dedica a Michel Foucault (HABERMAS, 2000). 
caso, temos a figura de uma verdade que está disposta em todos os lugares e em todos os momentos, que não tem qualquer descontinuidade, e que é, por isso, da ordem do universal. Evidentemente essas características não fazem com que essa forma de verdade seja facilmente apreendida; pois sua apreensão pode exigir longos processos de aprendizado, livrarmo-nos de preconceitos, corrigir nosso olhar, ou aprender a usar ou inventar instrumentos. Esta série histórica é aquela que prevalece no saber científico moderno, e em boa parte da filosofia. Segundo Foucault, para esta forma de pensamento:

A verdade pode muito bem estar soterrada, ser difícil de alcançar, mas tudo isso remete apenas a nossos próprios limites, às circunstâncias nas quais nos encontramos. A verdade nela mesma percorre o mundo todo, ela nunca é interrompida. Não há buraco negro na verdade [...]. Para falar mais esquematicamente, digamos que temos aí certa posição filosófico-científica da verdade que é ligada a certa tecnologia da construção ou da constatação em direito universal da verdade, uma tecnologia da demonstração. Digamos que temos uma tecnologia da verdade demonstrativa que se integra, em suma, com a prática científica (FOUCAULT, 2003, p. 235-236).

Contudo, Foucault constata haver historicamente outra posição da verdade, a qual foi recoberta, em parte, pela verdade-demonstração. Trata-se da série histórica que ele nomeia enquanto verdade-acontecimento, ou verdade-raio. Diferentemente da verdade demonstrativa, a verdade-acontecimento não é universal, pois é descontínua, não se apresenta em todos os lugares e momentos, mas sim em ocasiões específicas. O tempo desta verdade não é nem cronos, tempo da mortalidade dos homens e da medida instrumental, nem aiôn, tempo da imortalidade divina e do fluxo em que passado e futuro se misturam. O tempo da verdade-acontecimento é kairós, o instante qualitativo da ocasião. A verdade-acontecimento também não pode ser transmitida ou aprendida por qualquer um, mas tem seus agentes específicos. Esses agentes não são definidos por seguirem métodos ou regras gerais para o conhecimento, mas são aqueles que passam por iniciações, fazem rituais específicos os quais não os tornam exatamente aptos a alcançar a 
verdade, mas sim receptivos para que a verdade os alcance. Segundo as palavras de Foucault:

Esta seria a posição de uma verdade dispersa, descontínua, que somente falaria ou que só se produziria de tempos em tempos, lá onde ela quer, em certos lugares; uma verdade que não se produziria em todo lugar o tempo todo, nem para qualquer um; uma verdade que não nos espera, pois é uma verdade que tem seus instantes favoráveis, seus lugares propícios, seus agentes e portadores privilegiados. É uma verdade que tem sua geografia [...]. Esta verdade, com sua geografia, seus calendários, seus mensageiros ou seus operadores privilegiados, esta verdade não é universal. O que não quer dizer que seja uma verdade rara, mas que se trata de uma verdade dispersa, uma verdade que se produz enquanto um acontecimento (FOUCAULT, 2003, p. 236-237).

A verdade-acontecimento não pode ser descrita através da relação entre sujeito e objeto cuja ordem seria da contemplação ou do pensamento puro. Não se trata de qualquer forma de adequação, identidade ou de simpatia, e, no limite, essa relação para com a verdade não é uma pura relação de conhecimento. Segundo Foucault:

Entre esta verdade-acontecimento e quem é apreendido por ela, que a apreende ou que é atingido por ela, a relação não é da ordem do objeto ao sujeito. Logo, não se trata de uma relação de conhecimento; é antes uma relação de choque; é uma relação da ordem do raio, ou do relâmpago; é também uma relação da ordem da caça, em todo caso, uma relação arriscada, reversível, belicosa; é uma relação de dominação e de vitória, logo, não uma relação de conhecimento, mas de poder (FOUCAULT, 2003, p. 237).

Enquanto na verdade-demonstração as dificuldades para alcançar a verdade dizem respeito a não seguirmos o correto método universal, não termos progresso técnico suficiente, ou não sabermos ao certo os limites do conhecimento, na verdade-acontecimento os problemas para ser atingido pela verdade dizem respeito a não seguirmos os rituais necessários nos momentos específicos, a não sabermos escutar as palavras secretas, a não passarmos nas provações que nos tornam 
qualificados a entende-la. Esta separação é mais um marco da importância não apenas de Nietzsche para o pensamento de Foucault, mas também de seu contato com os trabalhos de helenistas como Gustave Gltoz, Pierre Vernant, Louis Gernet e Marcel Detienne. Estes foram estudiosos que se debruçaram sobre as transformações nas concepções de verdade (alétheia) na antiguidade, dando destaque para as bases materiais destas mudanças e sua articulação com práticas judiciárias, tema que cruza várias pesquisas de Foucault ${ }^{3}$. Detienne, por exemplo, chama atenção para uma concepção mais antiga de alétheia, encontrada no período micênico e em fontes arcaicas como Hesíodo ${ }^{4}$, permeada por elementos mágico-religiosos. Trata-se de uma verdade cuja relação com a memória e a luz não exclui o esquecimento (Lethes, que também designa uma das filhas da deusa da discórdia Eris), a escuridão, a discórdia, ou mesmo a mentira. Os operadores dessa forma de verdade, são os poetas, os adivinhos, oráculos, e o rei que distribui a justiça através da ordália. Segundo Detienne, neste caso:

A 'verdade' se institui pela aplicação correta, ritualmente completada, do procedimento. Quando, em nome dos deuses, ele preside o julgamento ordálico, o rei 'diz a verdade' ou, mais ainda, ele veicula a 'verdade'. Como o poeta, como o adivinho, o rei é 'Mestre da Verdade'. Sobre esses planos de pensamento, a 'verdade' é então sempre ligada a certas funções sociais; ela é inseparável de certos tipos de homens, de suas qualidades próprias e de um plano do real definido pela função desses homens na sociedade arcaica (DETIENNE, 2006, p. 111).

A versão privilegiada de uma verdade vinculada unicamente ao logos, em que o esquecimento, a escuridão, a discórdia e a mentira se opõem à verdade ao invés de complementá-la, é tardia, tendo nascido no período clássico.

\footnotetext{
Sobre isso, ver a tese de Fabiano Incerti, notadamente sua primeira parte (INCERTI, 2013, p.15-61).

4 É importante lembrar que Hesíodo é mencionado em A ordem do discurso: “Entre Hesíodo de Platão, certa divisão se estabeleceu, separando o discurso verdadeiro e o discurso falso; separação nova visto que, doravante, o discurso verdadeiro não é mais o discurso precioso e desejável, visto que não é mais o discurso ligado ao exercício do poder" (FOUCAULT, 2006a, p.15).
} 
Certamente, reflexões como as de Detienne fornecem as bases para a separação estabelecida por Foucault. Contudo, Foucault também encontra nessa figura mais arcaica da verdade-acontecimento, elementos que o ajudam a construir seu próprio pensamento. Isso significa que ele incorpora algumas das características da verdade-acontecimento para construir uma história da verdade na qual aquilo que está em questão não são figuras mágico-religiosas, mas os rituais sociais e institucionais de produção da verdade, os efeitos que a verdade produzida, por sua vez, também produz. Tudo isso é muito mais importante que o viés descritivo de suas pesquisas. Segundo Foucault:

Eu gostaria de fazer valer a verdade-raio contra a verdade-céu, ou seja: mostrar de um lado como esta verdade-demonstração, - sobre a qual é completamente inútil negar a extensão, a força e o poder que ela exerce atualmente -, como essa verdade-demonstração na verdade deriva da verdade-ritual, da verdade-acontecimento, da verdade-estratégia, como a verdade-conhecimento, no fundo, é apenas uma região e um aspecto que se tornou pletórico, tendo tomado dimensões gigantescas, mas um aspecto ou uma modalidade ainda, da verdade enquanto acontecimento e da tecnologia desta verdade-acontecimento (FOUCAULT, 2003, p. 238).

De fato, podemos dizer que uma das principais características das pesquisas de Foucault passa por mostrar de que modo vários dos conteúdos de conhecimento não revelam a sua essência imutável das coisas, mas a inventam. A partir de 1970, essa invenção não é mais estudada a partir da variação histórica das regras internas dos saberes, mas a partir de sua articulação com as relações de poder. Nos estudos genealógicos, o viés agonístico da alétheia é ressaltado a partir de uma revisão da concepção de poder da teoria política clássica. Ao fim e ao cabo, Foucault está integrando em seu próprio pensamento, isto é, em sua metodologia, esta concepção acontecimental de verdade, de modo a mostrar como a verdade-demonstração não pode prescindir de seus rituais, ter seus agentes privilegiados, seus espaços e tempo propícios ou desfavoráveis. Esses elementos, por sua vez, não são regras universais para o conhecimento do objeto, mas condições históricas de 
possibilidade para esses saberes, as quais dependem não de um progresso da razão, mas de relações de força entre os homens. Logo, um dos sentidos mais gerais do pensamento foucauliano é mostrar como muitas das verdades que nos habituamos a compreender apenas a partir do eixo da verdade-demonstração, nada mais são que formas de verdade-acontecimento que não se apresentam, ou mesmo se recusam a se apresentar enquanto tal. Mas isso é feito considerando a sua própria investigação nos termos de uma verdade-acontecimento.

\section{Verdade-acontecimento e experiência: uma verdade ficcionante}

Pensamos que esses elementos da verdade-acontecimento vão ser retrabalhados por diversas vezes no pensamento de Foucault, ganhando novas dimensões, mas sem perder algumas de suas características fundamentais. Na maioria das vezes, esses elementos serão revisitados quando Foucault interroga seu próprio pensamento, tal como nos trechos que apresentamos antes. Outro caso será sua longa entrevista com o jornalista e filósofo italiano Duccio Trombadori, realizada em 1978 e publicada em 1980. Ao ser interrogado sobre seus procedimentos metodológicos e sobre as mudanças em seu pensamento, Foucault diz que seus livros são como experiências e funcionam enquanto ficções, mas num sentido muito específico do termo.

Primeiramente, quando interrogado sobre uma concepção de experiência originária que supostamente estaria presente em História da loucura, e sobre quais elementos permanecem estáticos em seu pensamento, e quais foram abandonados, Foucault vai responder usando precisamente uma concepção de experiência que talvez seja um dos elementos de permanência:

Eu nunca penso exatamente a mesma coisa pela razão que meus livros são como experiências para mim, e isso no sentido que eu gostaria que fosse o mais pleno possível do termo. Uma experiência é algo de que se sai transformado [...]. Eu sou um experimentador no sentido em que escrevo para transformar a mim mesmo e não pensar mais a mesma coisa que antes (FOUCAULT, 2001, p. 860-861). 
Contudo, diferentemente da experiência fenomenológica, essa experiência não visa captar, a partir de um olhar reflexivo, as significações de um objeto qualquer do vivido, para então buscar sua fonte originária nas funções transcendentais de um sujeito fundador da experiência e de suas significações. Diversamente, para Bataille e Blanchot, "uma experiência é tentar chegar a um ponto da vida que seja o mais próximo possível do invivível. Aquilo que é requerido é o máximo de intensidade e, ao mesmo tempo, de impossibilidade"; o que significa dizer que a experiência não encontra, nas funções transcendentais do sujeito, um fundamento, mas que ela acaba por "[...] arrancar o sujeito de si mesmo, de fazer com que ele não seja mais ele próprio ou que seja levado ao seu esvaziamento ou à sua dissolução. Trata-se de uma empreitada de dessubjetivação [dé-subjectivaction no original]" (FOUCAULT, 2001, p. 862). Evidentemente, Foucault está se referindo mais especificamente à obra A experiência interior, e, talvez, ao conjunto maior da Summa Ateológica, de Georges Bataille, assim como se refere à leitura que Maurice Blanchot fez dessas obras em A afirmação e a paixão do pensamento negativo ${ }^{5}$.

Aos poucos, começa a ficar muito claro como essa concepção de livro-experiência não é absolutamente oposta a toda e qualquer verdade. Ao fim e ao cabo, ela parece ser irredutível a uma concepção específica de verdade, isto é, ao conjunto serial histórico daquilo que, em 1974, Foucault nomeou de verdade-constatação. Aquilo que Foucault prioriza em seus próprios livros não é exatamente o fato de que eles precisem se referir ao real, o que não deixa de ser incontornável. Todavia, muito mais importante é o fato de seus livros se enfrentarem com aquilo mesmo que eles descrevem, assim como o fato de eles serem um convite para que os outros façam parte dessa confrontação. Semelhante conflito apresenta uma dimensão claramente ético-política:

5 Sobre isso, ver 0 artigo "A presença de Georges Bataille no pensamento de Michel Foucault: entre o ser da linguagem, insurreição e atitude crítica" (GALANTIN, 2017, p. 213-228), e 0 capítulo "Notas sobre o Prefácio à Transgressão de Michel Foucault: linguagem, transgressão e negatividade" (GALANTIN, 2018, p.297-332). 
Meu problema é fazer eu mesmo e convidar os outros a fazerem junto a mim, através de um conteúdo histórico determinado, uma experiência daquilo que nós somos, do que é não apenas nosso passado, mas também nosso presente, uma experiência de nossa modernidade tal que saiamos dela transformados. O que significa que, ao final do livro, nós possamos estabelecer novas relações com aquilo que está em questão: que eu que escrevi o livro, e aqueles que os leram, tenham outra relação para com a loucura, para com seu estatuto contemporâneo e sua história no mundo moderno (FOUCAULT, 2001, p. 863).

Na medida em que as verdades dos livros de Foucault devem afetar a todos aqueles que os leem, podemos afirmar que sua característica mais fundamental não é o fato de apresentarem uma verdade essencialmente igual a todas as pessoas em todas as ocasiões e lugares, devendo finalmente repousar na história da filosofia após ter sido arduamente descoberta. Para Foucault, o viés de liça e desafio, de provação diante do real, o qual faz com que não aceitemos tacitamente enquanto necessários os saberes e os poderes que permeiam nosso cotidiano, é o aspecto mais importante de seus livros. Este viés é o responsável por fazer de seus livros verdadeiras experiências. Os psiquiatras que encontraram em livros como História da loucura, e os agentes penitenciários e juízes que encontraram em Vigiar e punir algo que impedia que eles trabalhassem da mesma forma como vinham trabalhando até então, perceberam, mesmo que involuntariamente, essa dimensão da verdade que altera aqueles que entram em contato com ela. Foucault espera que essa dimensão de experiência afete também aqueles classificados enquanto normais, e aqueles que jamais passaram ou conheceram alguém que passou pela justiça criminal ou pela criminalidade. Esta dimensão é a dimensão acontecimental da verdade, que faz dela também uma ficção:

[...] o essencial não se encontra na série de constatações verdadeiras ou historicamente verificáveis, mas antes na experiência que o livro permite fazer. Oras, essa experiência não é nem verdadeira nem falsa. Uma experiência é sempre uma ficção; é algo que se fabrica a si mesmo, que não existe antes e que existirá depois. Esta é a difícil relação para com a verdade, a maneira como esta se encontra engajada numa experiência 
que não está ligada a ela e que, até certo ponto, a destrói (FOUCAULT, 2001, p. 864).

Uma experiência apenas é verdadeira ou falsa quando estamos pensando a verdade unicamente em sua dimensão de constatação. Contudo, se a verdade-constatação pode pensar a si mesma enquanto algo que prescinde da ficção, sendo restrita à descrição e à adequação com relação ao real, a verdade-acontecimento por um lado mostra como essa verdade-constatação não deixa de produzir efeitos de realidade. Por outro lado, considerando a si mesma enquanto verdade-acontecimento, ela não se furta em admitir a produção de efeitos de realidade. Logo, ambas as verdades são ficcionantes. Neste sentido, um livro-experiência não apresenta, com relação ao real, uma relação de adequação, de pacificação, de quietismo sábio, mas de agonismo e de disputa. É neste sentido que Foucault pode dizer que, até certo ponto, essa experiência mantém, para com a verdade, uma relação de destruição. Contudo, o viés ficcional da experiência não remete a uma pura e simples anulação mágica ou aniquilação material daquilo que é descrito. A ficção até certo ponto destrói a verdade à qual ela se refere ao produzir uma perda de sua justificação ontológica, mostrando que ela nada mais é que um acontecimento, com seus agentes privilegiados, seus rituais e suas ocasiões favoráveis e desfavoráveis. Logo, é neste sentido que, usando a reflexão de Foucault de 1974, podemos dizer que a experiência ficcionante pode ser pensada nos termos de uma verdade-acontecimento:

Assim, o jogo da verdade e da ficção - ou, se vocês preferirem, da constatação e da fabricação - permitirá fazer aparecer claramente isso que nos liga - de modo totalmente inconsciente - à nossa modernidade, e, ao mesmo tempo, o fará aparecer alterado. A experiência pela qual nós compreendemos de modo inteligível certos mecanismos (por exemplo, o aprisionamento, a penalização, etc.), e a maneira através da qual nós conseguimos nos desvincular deles ao percebê-los de outra forma, deve ser uma coisa só. Isso é verdadeiramente o centro daquilo que eu faço (FOUCAULT, 2001, p. 865).

Podemos dizer que, se nesta entrevista há certa continuidade com o tema de uma verdade-acontecimento apresentado anteriormente, é 
preciso ressaltar que o tema da relação entre verdade e luta, isto é, a dimensão agonística da verdade, passa a incluir, a partir de 1978, a figura da ética. Este é um dos sentidos principais da noção de experiência enquanto alteração ética de si, vinculada a uma alteração política do mundo, a qual não estava claramente presente nestes termos em 1974. E a dimensão ética está presente não apenas quando Foucault diz que seus livros devem provocar uma alteração na relação que temos com os objetos em questão, com nós mesmos e com os outros, o que sem dúvidas é o ponto central desta noção. Essa dimensão de alteração ético-política do vínculo entre verdade-experiência-ficção também é usada por Foucault para revisitar parte de sua formação filosófica marcada pelo hegelianismo, e o engajamento político de sua juventude que tanto o decepcionou. Segundo Foucault,

o interesse por Nietzsche e Bataille não era uma maneira de nos distanciarmos do marxismo ou do comunismo. Ele era a única via de acesso àquilo que nós esperávamos do comunismo. A rejeição do mundo no qual nós vivíamos certamente não era satisfeita pela filosofia hegeliana. Nós estávamos à procura de outras vias para nos conduzir rumo a esse totalmente outro que nós imaginávamos incarnado pelo comunismo (FOUCAULT, 2001, p. 869).

Foucault rapidamente aprendeu que no Partido Comunista Francês não havia espaço para esse tipo de pensamento ou de engajamento, exceto sob a forma da obediência irrestrita às posições do partido junto a uma anulação de si mesmo. Contudo, essa noção de experiência, que marcou seu engajamento e seu confronto com a formação recebida, fornece as bases para um fundo ético-político na constituição de seu próprio pensamento. Na experiência evocada há uma dimensão de alteridade, melhor descrita nos termos de uma alteração: "Para mim a política foi a ocasião de fazer uma experiência à la Nietzsche ou à la Bataille [...]. Nós queríamos um mundo e uma sociedade não apenas diferentes, mas que fôssemos um outro nós mesmos; nós queríamos ser completamente outros num mundo completamente outro" (FOUCAULT, 2001, p. 868). Ao que tudo indica, essa alteração de si e do mundo implícita na noção de experiência evocada pode ser inserida 
na série da verdade-acontecimento, uma vez que ela marca certa confrontação agonística com o mundo. Ademais, se pensarmos o esquecimento numa dimensão ético-reflexiva de esquecimento ativo de si mesmo, este tornar-se completamente outro continua habitando a ambiguidade desta forma de verdade.

\section{Parresía, cinismo e verdade-acontecimento}

Se a série da verdade-acontecimento é mais facilmente encontrada no momento micênico e arcaico da Grécia, mesmo Marcel Detienne afirma que a ruptura instaurada por um discurso centrado nos aspectos lógicos da verdade, e que Foucault nomeia verdade-demonstração, nunca foi absoluta. Mesmo a filosofia clássica e a sofística carregam elementos da ambiguidade do sentido arcaico da alethéia (DETIENNE, 2006, p. 237-239). Ao que parece, Foucault pode ter encontrado alguns desses elementos no pensamento de Nietzsche, Bataille e Blanchot, e pensamos ser possível que esta mesma dimensão da verdade-acontecimento oriente suas investigações derradeiras sobre a relação entre ética e verdade na antiguidade greco-romana. Quando Foucault investigar a parresía na antiguidade, quase nenhum dos elementos que definem essa forma de dizer-verdadeiro remetem ao enunciado, isto é, ao conteúdo daquilo que é dito. A maior parte das características definidoras da parresía serão os elementos que a inserem na dimensão do acontecimento, isto é, a enunciação.

Na aula de 12 de janeiro de 1983 do curso Do governo dos vivos, Foucault vai estabelecer algumas das características gerais da parresía em todas as escolas filosóficas. Estas características são descritas de modo a separar a parresía dos atos performáticos de linguagem estudados por Austin e Searle. A primeira delas diz respeito ao fato que, ao invés de produzir um efeito previamente codificado por um campo institucional, a parresía abre uma indeterminação na situação de enunciação, assim como um risco para aquele que a enuncia, o qual pode chegar até sua própria morte. Diferentemente de uma explicação, que não envolve risco, ou de uma sentença enunciada por um juiz e ratificada por um sistema de justiça, a parresía produz uma abertura de 
indeterminação numa situação e um risco para aquele que fala. Por isso, segundo Foucault, trata-se de "[...] um dizer-a-verdade irruptivo, um dizer-a-verdade que fratura e que abre o risco: possibilidade, campo de perigos, ou em todo caso eventualidade não determinada" (FOUCAULT, 2010b, p. 61).

A segunda característica diz respeito à relação entre aquele que enuncia algo, e aquilo que é enunciado. Enquanto no caso de uma sentença jurídica moderna, aquele que enuncia não se vincula àquilo que é dito, a vinculação entre quem enuncia e aquilo que é enunciado publicamente é fundamental para a parresía. Contudo, se a questão do enunciado está presente, sua dimensão parresiástica não são as regras lógicas que ele segue, mas sim a relação estabelecida por aquele que enuncia com aquilo que ele diz. Na parresía, aquele que diz precisa dar sinais de comprometimento com relação à verdade que é dita, e, no limite, isso se dá pela maneira como se vive. Deste modo, há um pacto do sujeito consigo mesmo que o liga ao enunciado, e por este pacto se lança um desafio a uma situação, desafio que requer coragem do enunciador:

E esse ritual solene do dizer-a-verdade em que o sujeito compromete o que ele pensa no que ele diz, em que atesta a verdade do que pensa na enunciação do que diz, é isso que é manifestado por essa cena, essa espécie de liça, esse desafio (FOUCAULT, 2010b, p. 62).

Tal comprometimento requer coragem por parte do enunciador, independe de seu estatuto social, constituindo-se enquanto a terceira e última característica que torna a parresía irredutível a um enunciado performativo.

Ao que parece, com o tema da parresía, continuamos nos movimentando dentro do eixo de uma verdade entendida nos termos de acontecimento. Não estão em questão as regras formais que separam aquilo que é dito nos termos de verdadeiro ou falso, mas certas condições ritualísticas que precisam ser preenchidas. Para que um determinado enunciado possa ser considerado parresiástico, é preciso que ele preencha requisitos de ocasião. Apesar do indivíduo não fazer valer seu estatuto social, ele faz valer a sua coragem, o que também diz respeito a uma verdade que não está distribuída em todo lugar para 
todos. Sem esses aspectos, esse mesmo enunciado não será considerado parresiástico.

Contudo, pensamos ser importante trazer em cena a figura específica da parresía cínica, estudada por Foucault em A coragem da verdade no ano de 1984. Esta importância se dá tanto pela parresía ter sido considerada por Foucault um elemento da genealogia da atitude crítica (FOUCAULT, 2010b, p. 317), quanto pelo curso sobre o cinismo poder ser "como um testamento filosófico" em que Foucault inscreve "a totalidade de sua obra crítica" (GROS, 2009, p. 314). Gostaríamos de destacar que, neste caso, a importância do caso cínico antigo também parece se dar pelo fato de encontrarmos ainda um novo elemento que poderia vincular a parresía à verdade-acontecimento. Trata-se do elemento que faz da parresía uma forma de verdade que diz respeito à alteridade, trazendo em cena elementos da lethes, como o agonismo e obscuridade.

Foucault descreve o cinismo fundamentalmente através do tema da vida verdadeira (alethès bíos). Contudo, para entendermos o sentido do termo "verdadeira", é preciso destacar o modo pelo qual os quatro sentidos da verdade, recorrentes na cultura grega, são, de certa forma, transvalorados pela vida cínica. Quando esses valores, geralmente atribuídos ao logos, são rebatidos sobre a vida, a vida verdadeira, no caso cínico, torna-se uma vida que joga com os limites do aceitável pela cultura grega. Isso faz da vida verdadeira cínica algo irredutível às formas de vida das outras escolas.

Vejamos esses quatro valores da verdade e como o cinismo os transvalora. O primeiro valor da verdade é a não dissimulação. Normalmente a vida não dissimulada é aquela que não esconde nada de si mesma ao outros, pois nunca faz algo de que se deve envergonhar. Trata-se de levar uma vida que não desempenhe um duplo papel, um privado e outro público, mas sempre um e o mesmo. Contudo, no caso cínico, a verdadeira vida é dramatizada em sua materialidade, de modo a tornar público todos os seus elementos. Assim, os cínicos comem (o que não era bem visto na sociedade grega) e dormem em público (eles não têm casa), mas também fazem suas necessidades, se masturbam e transam em público. Enquanto a vida verdadeira nas outras escolas filosóficas desembocava numa atitude de pudor, a cínica 
era desavergonhada como aquela dos cães. Neste sentido, como mostra Foucault, a vida sem nada oculto e que não se oculta em nada,

é logo acompanhada de uma reversão de seus efeitos, de modo que essa vida cínica, que é realmente a mais fiel ao princípio da não dissimulação, pelo próprio fato dessa radicalização, aparece como radicalmente outra, é irredutível a todas as outras [...] (FOUCAULT, 2009, p. 234).

O segundo valor da verdade é a não-mistura. A vida sem mistura era frequentemente associada a uma vida que não misturava prazeres elevados com prazeres baixos. Neste caso, as diferentes escolas filosóficas aconselhavam o desapego em relação às riquezas como parte da construção de uma vida independente, visto que toda busca desenfreada por riqueza nos torna escravos de nossas paixões. No caso cínico, contudo, essa vida que se afastava dos baixos prazeres implicava numa pobreza real, ativa e infinita. Ela chegava ao cúmulo da miséria e mendicância, mas também a uma estética da feiura extremamente avessa aos valores gregos. Assim, os cínicos se despojavam de seus bens, e faziam disso uma provação de existência, e não apenas um treino eventual para não se deixar abater por um infortúnio possível. Essa forma cínica de pobreza ativa também toca os limites da cultura grega na medida em que busca a feiura e se afasta da estética do belo, chegando ao cúmulo de aceitar a escravidão, a procurar ativamente a desonra e a humilhação. Para uma cultura que valorizava a imagem que deixamos de nossa posteridade aos outros, que valorizava positivamente a beleza das formas do corpo humano, assim como via na escravidão, na mendicância e na dependência em relação aos outros, o sinal da pior das vidas possível, a vida cínica beirava o inaceitável por buscar ativamente o pior (FOUCAULT, 2009, p. 237-242).

O terceiro valor da verdade é aquilo que é direito ou reto (droit no original). A vida direita, ou reta, na maioria das escolas filosóficas, era uma vida em conformidade com um logos indexado à natureza. Contudo, a vida filosófica conforme a natureza era frequentemente uma vida submissa ao nómos da cidade, ou seja, uma vida conforme as regras convencionadas pelos homens. Segundo 
Foucault, no caso cínico, essa vida frequentemente entrava em atrito com as convenções sociais, recusando o casamento e a família, e até tabus mais extremos como o incesto e a antropofagia. Logo, viver de modo direito, tal como a natureza prescreve, será um valor retomado de modo a fazer com que essa vida apareça como uma vida outra (FOUCAULT, 2009, p. 243).

O quarto valor da verdade é a soberania, isto é, aquilo que se mantém por si sem sofrer alteração, nem depender de algo externo a si mesmo. Assim, a vida soberana é outro tema fundamental nas escolas filosóficas. Geralmente ela era retratada não apenas através do lugar do rei a ser idealmente ocupado pelo filósofo, mas pelo fato de que a soberania mais fundamental é aquela que se tem sobre si mesmo. A vida filosófica é aquela capaz de encontrar felicidade apenas em si mesma, e, por isso, ela pode ajudar os outros a lidarem com seus infortúnios. Com os cínicos, contudo, não há qualquer comparação entre a hierarquia da alma e a de uma cidade bem organizada, nem temos a figura do filósofo que, por ser soberano de si, pode guiar a alma do príncipe e, com isso, a de toda a humanidade. A soberania cínica é uma constatação insolente: o cínico já é rei, filho direto de Zeus. Porém, rei oculto aos olhos dos homens por sua situação de miséria. Do mesmo modo, o cínico dispensa a educação (paidéia), pois sua alma é dotada de andreía, uma espécie de coragem que não precisa da formação pela qual passam os reis. Como rei, contudo, não se trata de governar diretamente os homens, mas de cuidar do cuidado de si dos homens, e daí sua herança socrática e seu viés de perturbação social (FOUCAULT, 2009, p. 248-260).

Segundo a leitura de Frédéric Gros, os quatro valores assumidos pelo logos verdadeiro expostos anteriormente, uma vez rebatidos sobre a vida nas demais escolas filosóficas, fazem com que esta vida assuma aquilo que ele nomeia um "estilo geral de identidade" (GROS, 2011, p. 58). Esse estilo de identidade confere à vida verdadeira, assim como à verdade, as características da resistência: trata-se daquilo que resiste às mudanças, às provações dos vícios, aos subterfúgios de toda ordem. Neste sentido, Gros ressalta que esta resistência deve ser pensada no sentido eidético do termo, e não político: “Quero dizer que se 
o alêthês logos resiste à exposição, à simplicidade da expressão, à lógica e à mudança, é porque ele tem por objeto e fundamento as essências, as Formas inteligíveis, e que sua resistência é apenas o reflexo da identidade perfeita das Ideias" (GROS, 2011, p. 57).

Ainda segundo Gros, no caso cínico a vida verdadeira (alethès bíos) se desdobra num "estilo geral de alteridade que emerge da aplicação direta e radical dos valores da verdade ao bios" (GROS, 2011, p. 63). Neste sentido, se com as outras escolas filosóficas seria possível falar em uma resistência eidética da verdade a qual dá forma ao bíos, no caso cínico podemos falar de uma "resistência ascética" da verdade (GROS, 2011, p. 61). A diferença entre uma resistência eidética e uma resistência ascética se passa da seguinte maneira: se, no caso das outras escolas filosóficas, a verdade é aquilo que resiste às provações da lógica, mas também às paixões incontroláveis, aquilo que não se deixa enganar pelas aparências sempre inconstantes, é porque ela assume a figura das essências e da eternidade das formas puras. Já no caso cínico, o filósofo faz uma decapagem da existência sem sair do plano da imanência a mais absoluta possível. Ao livrar a sua vida de tudo aquilo que não é necessário, e isso no plano da materialidade; ao se livrar daquilo que a natureza não demanda e roer a existência até atingir sua camada mais elementar, o cínico encontra a energia para relançar sua contestação infinitamente. Segundo Gros:

Esse elementar [cínico - nosso complemento] se opõe ao essencial [das outras escolas - nosso complemento]. Quero dizer que se o filósofo clássico coloca seu pensamento à prova a fim de alcançar uma verdade essencial que resiste absolutamente, e para isso deve atravessar as cortinas das aparências moventes e inconstantes, o cínico escava a imanência mesma de sua vida até conquistar um elemento que seria como a camada primeira, sólida e dura da imanência. Mas chegando neste elementar, ele obtém uma energia sem limites (GROS, 2011, p. 62).

De fato, a vida cínica apresenta uma singularidade que se destaca das outras escolas filosóficas quanto a seu modo de vida. Contudo, Gros parece exagerar nessa contraposição e, com isso, platoniza outras filosofias como o estoicismo que, por sua vez, não carrega qualquer 
remissão às formas puras e a um outro mundo ${ }^{6}$. Por isso, gostaríamos de complementar e deslocar a leitura de Gros, pois pensamos que a divisa proferida pelo oráculo de Delfos a Diógenes, e que no fundo é uma divisa cínica geral, talvez seja tão ou ainda mais importante para a definição da estilística de alteridade cínica do que a prevalência do bíos/ vida sobre o logos/discurso em relação à alétheia/verdade. Os temas do dinheiro, da moeda e da fabricação de moedas são recorrentes quando se trata da vida cínica, como as de Diógenes ou Crates: segundo Diógenes Laércio, Diógenes o cínico ou falsificou moeda, ou seu pai assim o fez (DIOGÈNE LAËRCE, 1965, p. 14). Outro episódio mencionado é que, ao consultar o oráculo de Delfos, este proferiu ao cínico a seguinte sentença: "altere o valor da moeda" (parakharáttein tò nómisma). Alterar ou reavaliar a moeda tem um sentido muito específico no caso cínico. Trata-se de apagar a efígie da moeda, não para enganar sobre seu verdadeiro valor, fazendo-o maior ou menor do que ele se mostra. Tratase de mostrar como as moedas, tal como elas são convencionadas pelos homens, já são enganosas, e o cínico é aquele que deve restituir-lhe seu verdadeiro valor. Ocorre, contudo, que nómisma compartilha do mesmo radical de nómos, ou seja, das leis e costumes. Logo, conforme Foucault: "mudar o valor da moeda também é tomar certa atitude com relação àquilo que é convenção, regra, lei" (FOUCAULT, 2009, p. 209).

Os cínicos conduzem os valores da verdade a seus respectivos limites, e, com isso, mostram que a verdadeira vida, na verdade, se apresenta para a maioria dos homens enquanto uma careta perturbadora da vida cotidiana que eles levam. Nas análises de Foucault, talvez os temas da careta e da condução aos limites se combinem na figura do espelho quebrado, todos recorrentes nesse curso. Foucault dirá que o cinismo é como o espelho quebrado da filosofia, aquele que, ao invés de devolver a auto-imagem que permite uma reconciliação e

6 É importante lembrar que o logos universal segundo a escola de Zenão é pensado como o logos identificado ao fogo-artesão de Heráclito. De modo que o corte ontológico instaurado pelo platonismo não é seguido pelo estoicismo apesar de sua filiação socrática. Contudo, essa observação recoloca o problema com o qual Gros tenta lidar, pois mesmo tratando-se de uma escola filosófica com preceitos ontológicos bastante singulares, o modo de vida estoico não difere tanto das outras escolas como difere o cínico. 
autoconhecimento, reflete uma figura que causa estranhamento para aqueles que o olham:

O cinismo teria de algum modo o papel de espelho quebrado para a filosofia antiga. Espelho quebrado em que todo filósofo pode e deve se reconhecer, em que ele pode e deve reconhecer a própria imagem da filosofia, o reflexo daquilo que ela é, daquilo que ela deve ser, o reflexo do que ele mesmo é e do que ele mesmo gostaria de ser. E, ao mesmo tempo, neste espelho ele descobre algo como uma careta, uma deformação violenta, feia, desengonçada [disgracieuse no original], em que ele não poderia em hipótese alguma reconhecer a si ou a filosofia (FOUCAULT, 2009, p. 214).

De certa forma, a figura do espelho quebrado remete a uma ideia de alteridade imanente, sendo aquilo que rompe toda forma de reconhecimento narcísico do Mesmo, aquilo que faz irromper o outro e o fora lá onde se espera a identidade e a interioridade. Contudo, essa irrupção do outro e do fora se dá na imanência da figura que, ao ser refletida, é alterada; por isso, sem qualquer remissão a uma dimensão pura de alteridade. Neste caso, a figura do espelho quebrado reintroduziria com maior força a distorção, um dos atributos de lethes da alethéia. Pensamos ainda que a figura de uma alteridade imanente, ou ainda melhor, de uma alteração, é aquilo que faz Foucault usar o par vida outra e mundo outro para caracterizar o cinismo. É a figura da alteração imanente que torna o cinismo irredutível às filosofias que mobilizam os temas do outro mundo e da outra vida. Da mesma forma, a alteridade imanente cínica também não combina outro mundo e vida outra, como no caso do platonismo e da gnose cristã, os quais sustentam que uma vida voltada para contemplação das Formas ou para a união com Deus, precisa ser uma vida diferente das convenções deste mundo. Evidentemente, ela também não combina outro mundo e outra vida, como na ortodoxia cristã que relega a felicidade ao encontro da alma com Deus após a morte. Ao trazer para seu seio o princípio de alterar o valor da moeda, o cinismo combina uma alteração da vida dos homens com uma alteração do mundo, logo, uma vida outra que conduz a um mundo outro. Neste sentido, a dimensão ético-política do princípio de 
alterar o valor da moeda conduz a uma militância no mundo e contra mundo, assumindo a forma da vida verdadeira, em conflito com as convenções da vida cotidiana. Segundo Foucault:

Vocês estão vendo assim que o cínico é aquele que, retomando os temas tradicionais da verdadeira vida na filosofia antiga, transpõe esses temas, reverte-os em reivindicação e afirmação da necessidade de uma vida outra. E depois, através da imagem e da figura do rei de miséria, ele transpõe mais uma vez essa ideia da vida outra em tema de uma vida cuja alteridade deve levar à mudança do mundo. Uma vida outra para um mundo outro (FOUCAULT, 2009, p. 264).

\section{Conclusão}

Se, como defende Frédéric Gros, este último curso com enfoque no cinismo é um testamento filosófico que de algum modo diz respeito à obra toda de Foucault, é porque ele permite nexos com outros momentos do pensamento foucaultiano. Podemos concluir afirmando que a história da verdade feita por Foucault assume a figura da verdade-acontecimento destacada em 1974. Neste sentido, trata-se de uma história da verdade que, assim como busca descrever como os saberes verdadeiros se dão na história articulados com relações de poder, formando acontecimentos, ela também visa produzir um acontecimento. Pensar a si mesma enquanto um acontecimento significa que essa história da verdade deve transformar o real que é descrito.

Quando, a partir de 1978, Foucault começa a constituir sua maneira singular de pensar a ética, ele vai descrever seus livros enquanto livros-experiência, os quais, por sua vez, carregam alguns dos sentidos da verdade-acontecimento. Contudo, o viés agonístico dessa verdade passa a incorporar uma dimensão ética da relação para consigo e para com os outros. Neste sentido, o livro deve alterar tanto a forma com que Foucault pensa, quanto se espera que ele se integre a uma dimensão coletiva de transformação ético-política relativa aos temas abordados, isto é, que o livro adquira uma dimensão social. Essa dimensão, proveniente não da constatação, mas da produção de uma transformação, 
é abordada tanto pelas noções de experiência quanto de ficção. Já em 1977, na entrevista As relações de poder passam pelo interior dos corpos, quando questionado sobre a dimensão ficcional de $A$ vontade de saber, Foucault escreve:

[...] eu sei muito bem que nunca escrevi nada além de ficções. Contudo, eu não quero dizer com isso que se trate de algo fora da verdade. Pareceme que existe a possibilidade de fazer trabalhar a ficção na verdade, de induzir efeitos de verdade com um discurso de ficção, e de fazer de modo que o discurso de verdade suscite, fabrique algo que não existe ainda, logo, que ele 'ficcione'. 'Ficciona-se' a história a partir de uma realidade política que a torna verdadeira, e, a partir de uma verdade histórica, se 'ficciona' uma política que não existe ainda (FOUCAULT, 2001, p. 236).

Mais uma vez, apenas do ponto de vista da verdade-constatação, a ficção está excluída da verdade. Já do ponto de vista da verdade-acontecimento, não apenas a verdade-constatação ficciona, como, assumindo a si mesma enquanto uma ficção, ela também produz efeitos de verdade. Ainda no final da década de 1970, quando Foucault vincula a noção de experiência a um movimento de dessubjetivação, notamos que ela carrega consigo um sentido de alteração imanente. Neste sentido, esta alteração se constitui enquanto uma autoficção ético-política, pois vincula uma transformação ética que faz da vida uma vida outra, a uma transformação do mundo que faz deste um mundo outro

Finalmente, a própria forma com que Foucault descreve o enunciado parresiástico mostraria como ele também carrega vários elementos da verdade-acontecimento. Primeiramente porque aquilo que define esta forma de dizer verdadeiro não são as condições do enunciado, mas as condições de enunciação. E em segundo lugar, a parresía se liga à verdade-acontecimento devido a seu caráter ocasional e seu viés agonístico. No caso específico da parresía cínica, sua descrição através dos eixos do mundo outro e da vida outra faz com que ela se encontre num campo de sentido muito próximo daquele com que Foucault descreveu seus livros-experiência. De certa forma, os livros-experiência parecem 
assumir diante do mundo ao qual eles se referem uma relação de enfrentamento e alteração muito próxima àquela dos cínicos, sendo o mundo outro e a vida outra um elemento em comum a ambos. Pois ao mostrar como a aceitação tácita de determinados mecanismos de governo de si e dos outros por conteúdos de verdade não se justificam por si mesmos ou por uma razão pura, mas por sistemas históricos, os livros de Foucault convidam os homens a manter outras relações para consigo, com os outros, e com estas verdades.

É possível que boa parte da objeção que se faz ao pensamento foucaultiano, por este apresentar um déficit de normatividade crítica, provenha, dentre outros fatores, desta figura de uma alteração imanente. Apenas a partir de uma teoria pura ou filosofia primeira tomada primordialmente enquanto um conjunto de conhecimentos pode-se ter acesso a uma alteridade pura a partir da qual se pode julgar a política, a ética e a verdade a partir de um ponto sólido que servirá de critério avaliador. Apenas adotando, conscientemente ou não, num plano transcendente ou transcendental, as figuras do outro mundo e da outra vida, é que se pode fazer esse tipo de objeção. Logo, essa cobrança é impossível de ser atendida, pois Foucault de início parece fazer de seu pensamento um modo de fomentar um mundo outro e uma vida outra. Aqueles que encontram nesse déficit uma falha talvez pertençam a um regime de verdade demonstrativo, enquanto, para o regime acontecimental da verdade, esse déficit de normatividade é uma potência de pensamento.

\section{Bibliografia}

ARAÚJO, I. L. Foucault e a crítica do sujeito. Curitiba: Editora UFPR, 2008.

BLANCHOT, M. L'Entretien Infini. Paris: Gallimard, 2009.

BATAILLE, G. L'expérience intérieure. Paris: Gallimard, 2008.

CANDIOTTO, C. Foucault e a crítica da verdade. Belo Horizonte; Curitiba: Autêntica; Champagnat, 2010.

DETIENNE, M. Les maîtres de la vérité dans la Grèce archaïque. Paris : Librairie Générale Française, 2006. 
DIOGÈNE LAËRCE. Vie, doctrine et sentences des philosophes ilustres. Tome II. Paris : Flammarion, 1965.

FOUCAULT, M. A Ordem do Discurso. São Paulo: Edições Loyola, 2006a.

FOUCAULT, M. Dits et écrits. Tome II. Paris: Gallimard, 2001.

FOUCAULT, M. História da loucura. São Paulo: Perspectiva, 2012.

FOUCAULT, M. História da sexualidade: A vontade de saber. Rio de Janeiro: Graal, 2010a.

FOUCAULT, M. Le courage de la vérité: le gouvernement de soi et des autres II. Paris: Seuil; Gallimard, 2009.

FOUCAULT, M. Le pouvoir psychiatrique. Paris: Seuil; Gallimard, 2003.

FOUCAULT, M. O governo de si e dos outros. São Paulo: Martins Fontes, 2010b.

FOUCAULT, M. Vigiar e punir. Petrópolis: Vozes, 2006b.

GALANTIN, D. V. A presença de Georges Bataille no pensamento de Michel Foucault: entre o ser da linguagem, insurreição e atitude crítica. Revista Dois Pontos, Curitiba; São Carlos, 2017. p. 213-228.

GALANTIN, D. V. Notas sobre o Prefácio à Transgressão de Michel Foucault: linguagem, transgressão e negatividade. In: BUTTURI JUNIOR, A.; SEVERO, C. G. (orgs.). Foucault e as linguagens. Campinas: Pontes, 2018.

GROS, F. Foucault et la vérité cynique. Aurora, v. 23, n. 32, p.53-66, 2011.

GROS, F. Situation du cours. In: Le courage de la vérité. Op. Cit. 2009. p. 314-328. HABERMAS, J. O discurso filosófico da modernidade. São Paulo: Martins Fontes, 2000. INCERTI, F. O visível e o sonoro em Édipo-rei: uma leitura foucaultiana. Tese. Doutorado em Filosofia. São Paulo: PUC-SP, 2013.

MACHADO, R. Foucault, a ciência e o saber. Rio de Janeiro: Jorge Zahar, 2006.

Recebido: 14/01/2019

Received: 01/14/2019

Aprovado: $13 / 03 / 2019$

Approved: 03/13/2019 